\title{
The Relevance of Right and Left Hemisphere Classification to Predict Cognitive Outcome After Stroke
}

\author{
Savira Butsainah Dienanta, ${ }^{*}$ Muhammad Hamdan, $* *$ Soetjipto, $* * *$ \\ Abdulloh Machin**
}

\author{
*Faculty of Medicine, Universitas Airlangga, Surabaya, Indonesia \\ **Department of Neurology, Soetomo General Hospital, Faculty of Medicine, \\ Universitas Airlangga, Surabaya, Indonesia \\ ***Department of Psychiatry, Soetomo General Hospital, Faculty of Medicine, \\ Universitas Airlangga, Surabaya, Indonesia
}

\begin{abstract}
Introduction: Stroke is the fifth leading cause of disability-adjusted life years (DALYS) in the world. Cognitive impairment is one of the disabilities found in the acute phase of stroke and persists in long-term outcomes which can be assessed using the Mini-Mental State Examination (MMSE). However, a clinical classification to predict the cognitive outcome remained unclear. This study is aimed to identify differences of MMSE results in stroke patients between right and left hemisphere lesions to ensure the mentioned location classifications may contribute to cognitive outcome prediction.

Method: With the cross-sectional analytic observational design, 32 acute phase patients hospitalized in the Neurology Department Soetomo General Hospital from October-December 2019 were assessed using the Indonesian version of MMSE with purposive sampling and analyzed using the chisquare test.

Result: There was no significant difference between MMSE scores in right or left hemisphere lesion. This might happen because (1) MMSE was insensitive and not a domain-specific test; (2) a more specific infarct location was needed to predict cognitive outcome post-stroke, including microarchitecture of the brain especially those involved in the corticostriato-thalamocortical loop.

Conclusion: The right or left hemisphere lesion classification did not contribute significantly to predict cognitive impairment.
\end{abstract}

Keywords: Cognitive impairment, MMSE, Stroke

Korespondensi: Savira Butsainah Dienanta

E-mail: savira.butsainah.dienanta-2017@fk.unair.ac.id 
The Relevance of Right and Left Hemisphere Classification to Predict Cognitive Outcome After Stroke

\title{
Relevansi Klasifikasi Lesi Hemisfer Kanan dan Kiri dalam Memprediksi Gangguan Kognitif Pascastroke
}

\author{
Savira Butsainah Dienanta, * Muhammad Hamdan, ** Soetjipto, *** \\ Abdulloh Machin** \\ *Fakultas Kedokteran, Universitas Airlangga, Surabaya, Indonesia \\ **Departemen Neurologi, RSUD Dr. Soetomo, Fakultas Kedokteran, \\ Universitas Airlangga, Surabaya, Indonesia \\ ***Departemen Psikiatri, RSUD Dr. Soetomo, Fakultas Kedokteran, \\ Universitas Airlangga, Surabaya, Indonesia
}

\begin{abstract}
Abstrak
Pendahuluan: Stroke merupakan penyebab disabilitas kelima di dunia. Gangguan kognitif adalah salah satu masalah yang timbul pada stroke fase akut dan persisten dalam jangka panjang. Gangguan kognitif dapat diperiksa menggunakan MiniMental State Examination (MMSE). Namun, klasifikasi klinis untuk memprediksi gangguan ini masih belum jelas. Studi ini bertujuan untuk mengindentifikasi perbedaan skor MMSE pasien stroke lesi hemisfer kanan dan kiri untuk mengetahui apakah klasifikasi lokasi tersebut dapat memprediksi gangguan kognitif pascastroke secara signifikan.

Metode: Dengan jenis analitik observasional dan desain cross-sectional, 32 pasien fase akut yang dirawat inap di Departemen Neurologi RSUD Dr.Soetomo Surabaya diperiksa menggunakan MMSE versi Indonesia dengan teknik pengambilan sampel purposif dan dianalisis menggunakan tes chi-square.

Hasil: Tidak didapatkan perbedaan signifikan antara stroke kanan dan stroke kiri. Hal ini dapat disebabkan oleh (1) MMSE merupakan alat yang kurang sensitif dan tidak spesifik domain; (2) diperlukan lokasi infark yang lebih spesifik untuk memprediksi gangguan kognitif pascastroke, seperti mikroarsitektur pada otakyang berada dalam cortico-striato-thalamo-cortical loop.

Kesimpulan: Klasifikasi lokasi stroke menjadi lesi hemisfer kanan dan kiri tidak dapat memprediksi gangguan kognitif secara signifikan.
\end{abstract}

Kata kunci: Gangguan kognitif, MMSE, Stroke

\section{Introduction}

Stroke is defined as neurologic deficits marked by acute and focal tissue damage due to vascular problems. ${ }^{1}$ Stroke cases and mortality rates are increased in every country. Based on the data published by the World Health Organization, stroke is still considered the second leading cause of death in the world from 2000 until 2016. In 2000, there are 5.170.000 deaths caused by stroke, which represents $9,9 \%$ of total death in the world. This number is increased to reach 5.781.000 in 2016 with a percentage of $10,2 \%$ of total death in the world. In 2008, stroke contributes to $21,6 \%$ of deaths in Indonesia. ${ }^{2}$ Compared with another country, the case and mortality rate caused by stroke in Indonesia are still above the world average number. This mortality often occurs and thus the presence of post-stroke cognitive impairment cannot be observed. The mortality rate in patients with cognitive impairment that progress to vascular dementia is higher 2-6 times than patients without cognitive impairment. ${ }^{3}$

In 2000, stroke is also considered as the fifth-highest cause of disability-adjusted life years (DALYs) with the number of cases 2.004 in every 100.000 population. In 2016, this number decreased to 1.849 cases in every 100.000 population. Although this number is decreasing, stroke rank is increasing to be number two in causing DALYs. ${ }^{4}$ This shows that disability after stroke is not far from stroke severity in the acute phase. One of the problems happened in the acute phase is cognitive impairment. The severity of cognitive impairment is influenced by education, age, gender, social activity, risk factors, and comorbid factors. ${ }^{5}$ Stroke foci also takes a role in determining cognitive impairment because of lateralization. Ninety percent of right-handed and $60 \%$ of left-handed people use the left brain as their dominant hemisphere. ${ }^{6}$

There are many screening tools to examine the severity of cognitive impairment. One that has been used widely is the Mini-Mental State Examination (MMSE). 
As the score goes lower, the risk of having a cognitive impairment is higher. Due to brain lateralization, cognitive impairment severity may be influenced by stroke location. Batubara and Putri ${ }^{7}$ conducted a study in Batam and revealed that the left hemisphere stroke is more prone to cognitive impairment than the right hemisphere stroke. Yet, similar study has not been done in Surabaya. Thus, this study is aimed to identify MMSE score differences between right or left hemisphere lesions to ensure the mentioned location classifications may contribute to cognitive outcome prediction.

\section{Methods}

This is an analytic observational study with cross-sectional design. Participants were inpatients with recent stroke incidence within 4-14 days of stroke onset. Subjects were recruited from the Neurology Department Soetomo General Hospital Surabaya. Purposive sampling was used. Inclusion criteria for this study were: 1) ability to give consent to be a participant in this study; 2 ) aged $21-80$ years; 3 ) first stroke attack (ischemic or hemorrhagic acute stroke were included); 4) having a normal level of consciousness (Glasgow Coma Scale (GCS) was E4M6V5); 5) hemodynamically stable and active mobilization; 6) Manual Muscle Testing (MMT) score 3 or more; 7) literate. Exclusion criteria were 1) aphasia; 2) delirium; 3) uncooperative patients; 4) history of pre-stroke dementia. Based on those inclusion and exclusion criteria, 32 patients were recruited from October 14, 2019, until December 4, 2019. Participants' information about gender, age, educational background, social activity, risk factors, and comorbid diseases were collected using interviews and confirmed using medical records. Data were processed and analyzed using chi-square in Statistical Packages for the Social Sciences (SPSS) 25.

This study was approved by RSUD Dr. Soetomo Surabaya ethical committee (No. 1429/KEPK/VIII/2019). Before collecting data, samples were given informed consent by the neurology residents about current stroke conditions and cognitive functioning. After giving consent, the examination was conducted. Subject rights were guaranteed by using a closed envelope to store the examination data. The envelope was placed in a locked filing cabinet. Thus, the opening is restricted to the public other than the study team.
The independent variable assessed in this study was stroke location, classified as right and left hemisphere stroke. The dependent variable was the MMSE score. During hospitalization, MMSE was conducted after stroke patients reach stable conditions within 4-14 days after onset. It is a 30-item questionnaire that assesses some cognitive domains in a brief, such as orientation, attention, calculation, immediate memory, recall memory, language, and visuospatial construction. Each function is given points based on the participants' answers. The minimum score is 0 and the maximum score is 30 . There are two score interpretations, which are normal (if the score is 24-30) and abnormal (if the score is 0-23). The abnormal score indicates the probability of having cognitive impairment after stroke.

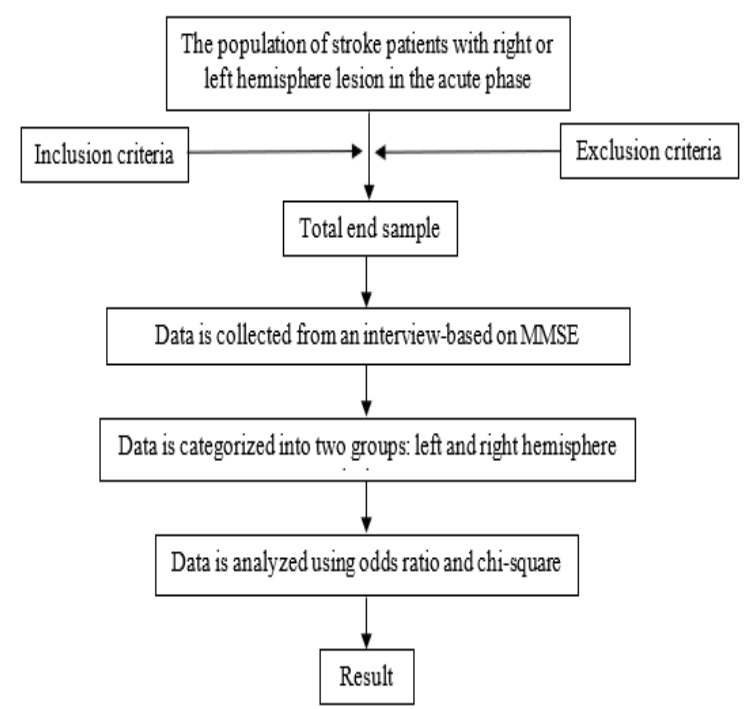

Diagram 1. Research Procedure

\section{Results}

\section{Characteristics of Participants}

There were 32 patients recruited in this study, with details as shown in Table 1. Stroke patients in Soetomo General Hospital were dominated by men. Participants in the middle age group (46-65 years old) were the highest among the other age groups. Most participants were senior high school-graduates. More than half of the samples had a job. The most frequent risk factor in stroke patients was hypertension, followed by diabetes mellitus. Ischemic stroke was found more often than hemorrhagic stroke. The incidences of the right and left hemisphere lesions were almost the same. 
Table 1. The Characteristics of the Participants

\begin{tabular}{|c|c|c|}
\hline Variables & $\mathbf{N}$ & $\%$ \\
\hline \multicolumn{3}{|l|}{ Gender } \\
\hline Men & 23 & 71,9 \\
\hline Women & 9 & 28,1 \\
\hline \multicolumn{3}{|l|}{ Age } \\
\hline $26-45$ & 3 & 9,4 \\
\hline $46-65$ & 21 & 65,6 \\
\hline $66-80$ & 8 & 25 \\
\hline \multicolumn{3}{|c|}{ Educational Background } \\
\hline Elementary school & 5 & 15,6 \\
\hline Junior high school & 5 & 15,6 \\
\hline Senior high school & 17 & 53,1 \\
\hline Diploma & 2 & 6,3 \\
\hline Bachelor degree & 1 & 3,1 \\
\hline Master degree & 2 & 6,3 \\
\hline \multicolumn{3}{|l|}{ Social Activity } \\
\hline Working & 20 & 62,5 \\
\hline Retired & 6 & 18,8 \\
\hline Not working & 6 & 18,8 \\
\hline \multicolumn{3}{|l|}{ Risk Factor } \\
\hline Hypertension & 22 & 68,8 \\
\hline Diabetes mellitus & 9 & 28,1 \\
\hline Dyslipidemia & 4 & 12,5 \\
\hline \multicolumn{3}{|l|}{ Stroke Type } \\
\hline Ischemic stroke & 20 & 62,5 \\
\hline Hemorrhagic stroke & 12 & 37,5 \\
\hline \multicolumn{3}{|l|}{ Stroke Location } \\
\hline Right hemisphere & 17 & 53,1 \\
\hline Left hemisphere & 15 & 46,9 \\
\hline Total & 32 & 100 \\
\hline
\end{tabular}

\section{MMSE Score Difference between Right and Left Hemisphere Lesion}

There was no significant difference between the MMSE score in right and left hemisphere lesion $(p=0,169)$. This result is shown in Table 2. This result indicates that the right and left hemisphere classification is not relevant to contribute to cognitive outcome prediction significantly.

Table 2. MMSE Score Difference between Right and Left Hemisphere Lesion

\begin{tabular}{|c|c|c|c|c|}
\hline \multirow{2}{*}{ Stroke Location } & \multicolumn{2}{|c|}{ MMSE Score } & \multirow{2}{*}{ Total } & \multirow{2}{*}{$\mathbf{p}$} \\
\hline & Abnormal & Normal & & \\
\hline Right hemisphere & $4(24 \%)$ & $13(76 \%)$ & $17(100 \%)$ & 0,169 \\
\hline Left hemisphere & $7(47 \%)$ & $8(53 \%)$ & $15(100 \%)$ & \\
\hline Total & 11 & 21 & 32 & \\
\hline
\end{tabular}

\section{Discussions}

\section{MMSE Score Difference between Right and Left Hemisphere Lesions}

Even though the abnormal percentage was higher in the left hemisphere stroke, there was no significant difference between the MMSE score in right and left hemisphere lesions $(p=0,169)$. This differs from the previous study by Batubara \& Putri ${ }^{7}$ which stated the left hemisphere MMSE score was significantly lower than the right hemisphere lesion. However, a study by Yoon et al. ${ }^{8}$ also reported no significance in stroke location causing cognitive impairment.

This not significant result may come because post-stroke cognitive impairment is a multifactorial problem, including gender, age, educational background, social activity, risk factor, size and location of the infarct. ${ }^{9}$ These lot of factors make cognitive evaluation cannot be done from hemisphere location only. In predicting post-stroke cognitive impairment, two indicators can be assumed as independent predictors, which are stroke location and domain-specific cognitive function test. ${ }^{10,11}$ Those two variables should be reviewed and evaluated in order to explain negative results in this study. Moreover, this study has a limitation to evaluate the size of the infarct and more specific locations other than the right or left hemisphere. This can be considered as a confounding variable.

The size of the infarct contributes in stroke severity. Stroke severity is examined when a patient is administered to the hospital in an acute phase. There are some tools to know stroke severity. One of them is National Institutes of Health Stroke Scale (NIHSS), which considers some points: (1) level of consciousness, (2) horizontal eye movement, (3) visual field test, (4) facial palsy, (5) motor arm, (6) motor leg, (7) limb ataxia, (8) sensory, (9) language, (10) speech, (11) extinction and inattention. If there are more abnormal signs found, the risk of having a cognitive impairment is also increased. This subject is proven from a significant relationship between stroke severity measured by NIHSS with cognitive impairment in the previous study by Ferreira et al. ${ }^{12}$ Another study also showed that loss of consciousness in acute phase stroke is a factor in intellectual dysfunction. ${ }^{13}$ This study has a limitation to evaluate stroke severity.

Cognitive function screening in acute phase stroke is a way to predict prognosis after a stroke attack. MMSE is one of the tools that 
had been used widely for dementia screening, along with the Montreal Cognitive Assessment (MoCA). There were a lot of studies using MMSE or MoCA as the instrument, but nowadays those instruments were reported less sensitive to predict cognitive impairment and the prognosis as well. MMSE was known as dependent on some factors, such as age, language, and education. MMSE was insensitive for the right hemisphere lesion and could not predict which domain was affected. MMSE also could not differentiate any diffuse or focal lesion. Cognitive domains such as abstract thinking, reasoning, executive function, insight and judgment, knowledge, and remote memory could not be observed using MMSE only. Therefore, another domain-specific neuropsychology test is needed to be a better prognosis predictor. ${ }^{11,12}$ In their study, Ferreira et al. ${ }^{12}$ used a two-hour comprehensive neuropsychology test to examine all cognitive domains and detect any subtle cognitive impairment. Those tests were Rey Auditory Verbal Language (RAVLT), Rey-Osterrieth Complex Figure Test (ROCFT), Mental Control, Numbers, Trail Making Test, Cancellation Test, and so on. Another study by Park et al. ${ }^{11}$ tested 4 types of domain-specific tests and searched which test was more sensitive to predict cognitive impairment post-stroke. Those tests were Boston Naming Test (BNT), Construction Recall Test (CRT), Construction Praxis Test (CPT), and Verbal Fluency Test (VFT) which evaluated speech and language, visuospatial construction ability, visuospatial memory, and executive function respectively. Among those tests, CPT and CRT were the best tests to predict functional improvement in 3 and 6 months after stroke. CPT examined visuospatial construction, while CRT examined memory function. These two cognitive domains were considered as the most influencing factor to determine long term cognitive outcomes. In MMSE, these two factors were also evaluated, but lacking the depth that could not detect any subtle disturbance. ${ }^{11}$

From the explanation above, it is known that MMSE has less sensitivity in predicting cognitive impairment. Therefore, caution may be needed to conclude any cognitive problem from MMSE only. ${ }^{12}$

In addition to a lack of domain-specific tests, this study also did not specify stroke location more than the right or left hemisphere. A study by Munsch et al. ${ }^{10}$ reported that stroke location is also a decent predictor of cognitive impairment. Various univariate analyses showed a correlation between cog- nitive impairment with age, gender, educational background, stroke severity, and infarct location. In multivariate analysis, if all components lead to cognitive impairment factors, the risk of developing cognitive problems is increased. Based on multivariate analysis, stroke location is the strongest predictor of cognitive impairment alongside clinical examination and past medical history. ${ }^{10}$ In short, there is a close relationship between specific cognitive domain and functional neuroanatomy, but not as simple as right or left hemisphere classification.

Research development showed that cognitive impairment pathophysiology can be caused in 2 ways: (1) multiple and large infarcts, and (2) small infarcts, but occurred in a strategic location..$^{14}$ One of the inclusion criteria in this study was the normal level of consciousness (Glasgow Coma Scale was E4M6V5), therefore, it was assumed that the average infarct size of the participants was relatively small.

Based on its topical diagnosis, vascular dementia can be classified into cortical and subcortical. Cortical vascular dementia (or multi-infarct dementia) is associated with large vessel occlusion and heart emboli. As a result, infarct may occur in area vascularized by this blood vessel and the distal area (watershed infarct). ${ }^{15}$ Multiple infarcts also contribute to the incidence of cognitive impairment and long-term intellectual dysfunction. ${ }^{13}$ Subcortical dementia or also called Subcortical Ischemic Vascular Disease syndrome (SIVD syndrome) is cognitive impairment caused by small vessel occlusion. SIVD may occur as a consequence of lacunar infarct, diffuse or focal white matter lesion, and incomplete ischemic injury. The pathway affected by this lesion is the cortical-subcortical circuits. White matter lesion is known contributes to problems in cognitive, mood, motoric, and micturition systems. This lesion may aggravate post-stroke cognitive impairment. ${ }^{15}$

As the theory about cortical and subcortical develops, it was found that stroke location responsible for determining cognitive function was more specific than right or left hemisphere classification. In 1993, a study by Schmidt et al. ${ }^{13}$ identified that the temporal lobe may play some role in cognitive function so that temporal lobe infarct was categorized as a high risk of developing cognitive impairment and long-term intellectual dysfunction. In 2009, Erkinjutti \& Gauthier ${ }^{15}$ also reported that medial temporal lobe atrophy took a role in memory impairment. Khedr et al. ${ }^{16}$ also 
found that the hippocampus, thalamus, and prefrontal cortex were considered as contributing areas to dementia due to their important role in learning and memory. Impairments in learning and memory were a consequence of other function problems, such as attention, speed of reaction, and short-term memory. Ferreira et al. ${ }^{12}$ also identified that the most common cognitive function impairment in stroke patients was attention and executive function.

A multivariate study about the correlation of strategic location with stroke signs and symptoms was needed. Zhao et al. ${ }^{14}$ conducted a multivariate study about this and revealed that there were strategic locations to affect the cognitive domain even with a relatively small infarct $( \pm 2,32 \mathrm{ml})$. Those strategic locations were the left basal ganglia and its white matter surrounding, named left angular gyrus, left caudate nucleus, left globus pallidus, left anterior corona radiata, anterior limb of the internal capsule, left external capsule, left posterior thalamocortical radiation, left superior frontooccipital fascicle, and left tapetum part of the corpus callosum. A systematic review by Mohd Zulkifly et al. ${ }^{17}$ stated that basal ganglia and paraventricular nucleus infarcts were a significant factor in cognitive impairment. These locations were associated with lacunar infarct.

Zhao et al. ${ }^{14}$ also stated that not all the mentioned areas gave a significant effect on global cognitive impairment. This study specified the association of strategic infarct location and the cognitive domain affected if there was infarct in those locations. Global cognitive impairment most likely occurs if the infarct was located in left inferior frontal gyrus, left medial temporal gyrus, and left basal ganglia. Language impairment was mostly caused by an infarct in medial temporal gyrus and right corona radiata. Memory impairment could occur due to the left medial temporal lobe and left/right basal ganglia infarct. Attention impairment could result from left anterior corona radiata, left corpus callosum, and left superior longitudinal fascicle infarcts. Executive function impairment was caused by an infarct in the left internal capsule and left posterior thalamic radiation. Visuospatial impairment could be a consequence of infarct in the left internal capsule, left external capsule, and left corpus callosum.

Among those areas, the most significant area in causing global cognitive impairment was an anterior limb of the internal capsule. This area was passed by projection fiber from the frontothalamic tract. ${ }^{18}$ This subject was reciprocal to a study by Khedr et al. ${ }^{16}$ which stated that infarct in the prefrontal cortex, thalamus, and hippocampus were the potential to cause cognitive impairment. Not only from mentioned areas, cognitive impairments can also occur due to infarcts in pathways connecting them. Infarcts that cause cognitive impairments occur more frequently in the internal capsule in the lacunar infarct area than the prefrontal cortex or hippocampus itself.

Based on all those studies, areas affecting the cognitive domain were connected in a pathway called cortico-striato-thalamocortical loop. Thalamus relays all sensory stimuli that have a role in the attention process to be passed to the prefrontal cortex. In addition thalamus also to send inhibition to other unnecessary stimuli through the thalamic reticular nucleus. Therefore, thalamus plays an important role as a sensory stimuli integrator. There was also a reciprocal stimulus sent from the prefrontal cortex to thalamus (especially the paraventricular nucleus) in the learning and acquisition process. ${ }^{19}$

Stimulation to the prefrontal cortex was also sent to the hippocampus as a part of the limbic system. Hippocampus gives emotional response to those information inputs and convert short-term to long-term memory. If later the information was needed by the prefrontal cortex, it would be restored by the hippocampus and sent back to the prefrontal cortex. $^{20}$

Basal ganglia has a strong relation to the prefrontal cortex because it receives all input from that area. Basal ganglia could influence executive function because it is also passed by the extrapyramidal pathway of motoric function through the indirect and direct pathway. Other than the motoric symptom, basal ganglia lesion also showed similar impairments with a lesion in the prefrontal cortex. This subject confirmed that the cortico-striato-thalamocortical loop was a pathway that connects this interrelationship. ${ }^{21}$

Subcortical lesion has a significant role in the occurrence of cognitive impairment. White mater in subcortical area contains a lot of myelinated fibers serves as projection, association, and commissural fibers. These fibers had important roles in the communication pathway inside the brain. If there was any lesion, the two hemispheres might not be connected and undergo some dysfunction. 18 Therefore, it could be concluded that not all infarcts in cortical and subcortical areas cause 
cognitive impairment.

The cortico-striato-thalamocortical loop was an area that control some distinct functions, such as language function in the left inferior frontal gyrus, left medial temporal gyrus, left medial occipital gyrus, and left angular gyrus. Memory and executive function were more related to a more various cortical and subcortical area in the left hemisphere.

Some cognitive functions were ruled by an overlapped area between right and left hemispheres. These functions include attention which involved various tract in right and left hemisphere white matter, and visuospatial function which involved some area distributed in the subcortical tract in right and left hemisphere and cortical temporoparietal area. ${ }^{14}$

From our study, the classification of right and left hemisphere lesion could not be a sole predictor of cognitive outcome in the acute phase. Further examination is needed to clarify the size and specific area of the infarct because not all areas in the left hemisphere prone to cognitive impairment and not all right hemisphere area is immune from cognitive impairment.

However, this study has some limitations. A more specific location that involved microarchitecture of the brain obtained from radiology examination is needed. Besides, the instrument used in this study is not a domain-specific cognitive function test. These subjects are expected to be an evaluation for further research development.

\section{Conclusions}

There was no significant difference in MMSE score between right and left hemisphere lesion stroke. Thus, the right and left hemisphere classification are not relevant to predict cognitive outcome after stroke. Further research with more advanced methodology is needed to evaluate the correlation between specific infarct location obtained from radiology examination and domain-specific cognitive function test to prove any differences in cognitive impairment in various areas of the brain.

\section{Conflicts of Interest}

The authors confirmed no conflict of interest.

\section{Acknowledgments}

All authors have seen and approved the final manuscript. SBD designed the outline concept of the research and wrote the initial draft. $\mathrm{MH}$, $\mathrm{S}$, and AM revised and expanded the manuscript.

\section{References}

1. Sacco RL, Kasner SE, Broderick JP, Caplan LR, Connors JJ, Culebras A, et al. An updated definition of stroke for the 21st century: A statement for healthcare professionals from the American heart association/American stroke association. Stroke. 2013;44(7):206489.

2. Tan CS, Müller-Riemenschneider F, Xian Ng SH, Tan PZ, Chan BPL, Tang KF, et al. Trends in stroke incidence and 28-day case fatality in a nationwide stroke registry of a multiethnic Asian population. Stroke. 2015;46(10):272834.

3. Teasell R, Salter K, Faltynek P, Cotoi A, Eskes G. Chapter 12: Cognitive Rehabilitation. Evidence-Based Rev Stroke Rehabil. 2019;(2000).

4. World Health Organization. Disease burden and mortality estimates [Internet]. 2018. Available from: https://www.who.int/healthinfo/\%0Aglobal_burden_disease/estimates/ en/index $1 . h t m l \% \overline{0} \mathrm{~A}$

5. Kim M, Park JM. Factors affecting cognitive function according to gender in community-dwelling elderly individuals. Epidemiol Health. 2017;39:e2017054.

6. Yogarajah M. Crash Course Neurology. 4th ed. Elsevier; 2015.

7. Batubara S, Putri C. Perbedaan Penurunan Fungsi Kognitif pada Pasien Stroke antara Lesi Hemisfer Kanan dan Kiri di Poliklinik Saraf RSUD Embung Fatimah Kota Batam. J Kedokt Sains dan Teknol Med. 2018;16-21.

8. Yoon JA, Kim DY, Sohn MK, Lee J, Lee SG, Lee YS, et al. Factors associated with improvement or decline in cognitive function after an ischemic stroke in Korea: The Korean stroke cohort for functioning and rehabilitation (KOSCO) study. BMC Neurol [Internet]. 2017;17(1). Available from: http://dx.doi. org/10.1186/s12883-016-0780-3

9. Putri M, Mutiawati E, Mahdani W. Hubungan Derajat Stroke Terhadap Status Kognitif Pada Pasien Stroke Iskemik Di Poliklinik Saraf Rumah Sakit Umum Daerah dr. Zainoel Abidin Banda Aceh Relationship Degree Stroke on The Cognitive Status Patients Ischemic Stroke. 2017;2:61-7.

10. Munsch F, Sagnier S, Asselineau J, Bigourdan A, Guttmann CR, Debruxelles S, et al. Stroke location is an independent predictor of cognitive outcome. Stroke. 2016;47(1):66-73.

11.Park J, Lee G, Lee SU, Jung SH. The impact of acute phase domain-specific cognitive function on post-stroke functional recovery. Ann Rehabil Med. 2016;40(2):214-22.

12.Ferreira MGR, Moro CHC, Franco SC. Cog- 
nitive performance after ischaemic stroke. Dement e Neuropsychol. 2015;9(2):165-75.

13. Schmidt R, Mechtler L, Kinkel PR, Fazekas F, Kinkel WR, Freidl W. Cognitive impairment after acute supratentorial stroke: a 6-month follow-up clinical and computed tomographic study. Eur Arch Psychiatry Clin Neurosci. 1993;243(1):11-5.

14.Zhao L, Biesbroek JM, Shi L, Liu W, Kuijf HJ, Chu WWC, et al. Strategic infarct location for post-stroke cognitive impairment: A multivariate lesion-symptom mapping study. J Cereb Blood Flow Metab. 2018;38(8):1299311.

15.Erkinjuntti T, Gauthier S. The concept of vascular cognitive impairment. Front Neurol Neurosci. 2009;24(Mid):79-85.

16.Khedr EM, Hamed SA, El-Shereef HK, Shawky OA, Mohamed KA, Awad EM, et al. Cognitive impairment after cerebrovascular stroke: Relationship to vascular risk factors. Neuropsychiatr Dis Treat. 2009;5(1):103-16.

17. Mohd Zulkifly MF, Ghazali SE, Che Din N, Singh DKA, Subramaniam P. A Review of Risk Factors for Cognitive Impairment in Stroke Survivors. Sci World J. 2016;2016.

18.Baehr M, Frotscher M. Duus' Topical Diagnosis in Neurology. 5th ed. Germany: Thieme Publishing Group; 2012.

19. Wolff M, Vann SD. The cognitive thalamus as a gateway to mental representations. J Neurosci. 2019;39(1):3-14.

20.Opitz B. Memory function and the hippocampus. Hippocampus Clin Neurosci. 2014;34:51-9.

21.Leisman G, Braun-Benjamin O, Melillo R. Cognitive-motor interactions of the basal ganglia in development. Front Syst Neurosci. 2014;8(FEB):1-18. 